BOGUMIŁA SZCZEPANIK-KRUSIŃSKA

Instytut Filozofii UMK

\title{
Inspiracje Thomasem Hobbesem w filozofii politycznej Robina George'a Collingwooda
}

T omasz Hobbes, podobnie jak Robin George Collingwood, był wielkim filozofem i naukowcem w swoich czasach. Obaj często wypowiadali się na rozmaite tematy niekoniecznie filozoficzne (w wypadku Hobbesa) czy historyczne (w wypadku Collingwooda). Niestety większość słowników i opracowań przedstawiało działalność powyższych filozofów w sposób niepełny, pomijając część wątków w ich twórczości. Dzisiejsze encyklopedie i omówienia opisują Hobbesa jako filozofa polityki, nie uwzględniając niejako całości jego twórczości. Hobbes oprócz filozofii zajmował się również nauką. Przykładowo, zasłynął on sporem z profesorem geometrii Johnem Wallisem czy innymi umysłami mu współczesnymi ${ }^{1}$. Jak pisze R. Tokarczyk: „dzięki wielkiej erudycji i genialnym uzdolnieniom mógł się wypowiadać w zakresie problematyki należącej do bardzo odległych od siebie gałęzi wiedzy: matematyki (w niej zaś geometrii), fizyki (w niej mechaniki i optyki), fizjologii, psychologii, antropologii, ekonomii, historii, literatury pięknej, teorii języka i mowy",

Podobnie rzecz się miała w wypadku Collingwooda. Celem niniejszego artykułu jest prezentacja jego jako filozofa polityki i specjalisty z zakresu filozofii kultury. Ten oksfordzki myśliciel był z wykształcenia historykiem, archeologiem i filozofem - niezwykle erudycyjne wychowanie sprawiło, że po-

Zob. R. Tokarczyk, Hobbes, Warszawa 1987, s. 24.

Tamże, s. 8. 
trafił się on z ogromnym znawstwem wypowiadać na szereg tematów począwszy od sztuki, poprzez psychologię, socjologię czy historiozofię. Jako sławny archeolog specjalizował się w okresie kolonizacji Brytanii przez antycznych Rzymian. Fascynacja ta i ogromna wiedza znalazła oddźwięk w szeregu jego prac.

Collingwood w swym myśleniu o historii był antypozytywistą, niezależnie od tego, czy wypowiadał się na temat historii we wcześniejszym okresie twórczości intelektualnej, czy pod koniec życia. Problemem idei historii, jej statusu jako nauki i związkach z filozofią zajmował się przez całą swoją działalność naukową, natomiast pewne kwestie z pogranicza filozofii polityki i historii dziejów (rozumianej jako refleksja nie o tym, czym jest historia jako dyscyplina akademicka, metodologią historii - bo nią zajmował się całe swoje życie - a raczej historiozofią jako krytyczną oceną otaczającej go rzeczywistości i ewentualne prognozy dotyczące przyszłości) poruszył dopiero pod koniec życia, gdy sam siebie nazywał filozofem walczącym. Do tego typu refleksji skłoniły go następujące, niepokojące wydarzenia społeczne i polityczne: dojście Hitlera do władzy, pierwsza wojna światowa, faszyzm.

Co było tak specyficzne dla jego filozofii? Według Witolda N. Nowaka Collingwood żył w czasach, „gdy moźliwe było jeszcze uprawianie filozofii historii na sposób spekulatywny, a nie analityczny" ${ }^{3}$. W jego dziełach było widać próbę budowania własnej koncepcji dotyczących rozmaitych kwestii, chociażby wspomnianej historii jako nauki czy cywilizacji i wizji idealnej wspólnoty. Nie można mimo to negować wpływu środowiska intelektualnego, w którym przebywał oraz klasycznego wykształcenia. Również nie bez znaczenia była kwestia jego licznych zapożyczeń, inspiracji i transkrypcji. Badacze po dzień dzisiejszy spierają się nad kwestią, czy był on bardziej twórczy czy odtwórczy w swych pracach. Sam oksfordzki filozof uważał, że wiedza to „wspólne dobro wspólnoty”.

Według rozmaitych koncepcji był on idealistą w duchu neoheglowskim, dla innych realistą i prekursorem filozofii analitycznej. Natomiast w opinii niektórych specjalistów nie był on ani realistą, ani idealistą, bo z tezami tych obu nurtów polemizowat. Jednak nikt z badaczy nie zanegował wpływu heglizmu czy monizmu, które to nurty były widoczne w dziełach

W. M. Nowak, R.G. Collingwood i F. Koneczny: dwie koncepcje cywilizacji, [w:] Koncepcje integracyjne w myśli narodów słowiańskich, red. Zygmunt Stachowski, Warszawa-Tyczyn 1999, s. 125. Tamże, s. 35.

Szerzej na ten temat pisze Jolanta Zdybel. Opisuje ona szczegółowo klimat intelektualny panujący wówczas w Oksfordzie (gdzie studiował i wykładał Collingwood), poszczególnych filozofów i ich intelektualny wpływ: J. Zdybel, Filozofia Robina George'a Collingwood'a, Lublin 1997, s. 15 i nast. 
Collingwooda. W wielu swych dziełach bardzo często odnosił się i inspirował filozofią antyczną ${ }^{6}$. Podobna sytuacja widoczna była także w innych pracach, jak w omawianym przeze mnie poniżej i kluczowym dla tego artykułu dziele: w Nowym Lewiatanie, a także w Esejach z filozofii polityki ${ }^{7}$. Kolejną z wielu inspiracji, która znalazła szerokie komentarze i odniesienia w poglądach filozofa było chrześcijaństwo i jego ideały.

Collingwood również niezwykle cenił znane dzieło wybitnego angielskiego filozofa i naukowca Thomasa Hobbesa. Nie bez znaczenia jest też fakt, iż sam Collingwood jedną z głównych prac dotyczącą filozofii politycznej i cywilizacji nazwał Nowym Lewiatanem. W przedmowie stwierdza nawet: „Wojny tego wieku pokazały nam, że u Hobbesa więcej było prawdy niż tłumaczyliśmy. Nauczyły nas, że aby ujrzeć życie polityczne takim, jakim ono jest, należy rozwiać opary sentymentalizmu, które - począwszy od początku XVIII w. - ukryły przed nami jego rysy" ${ }^{8}$. A przecież wojna była tak wstrząsającym wydarzeniem, z którego trzeba wyciągnąć naukę i którego trzeba unikać. Collingwood cytował nawet Tukidydesa, twierdzącego, że to historia jest srogą nauczycielką ${ }^{9}$. Nie ulega wątpliwości, iż wpływ na tę opinię miały osobiste doświadczenia filozofa, jak służba wojskowa w wywiadzie admiralicji podczas pierwszej wojny i okrucieństwo, jakiego doświadczył on sam lub jego koledzy filozofowie.

Nowy Lewiatan powstał pod koniec życia i został napisany w dużym pośpiechu. Miał on bardzo lapidarną formę numerowanych aforyzmów i z tego powodu cytaty z tej książki są podawane w literaturze fachowej numerowanymi rozdziałami, a nie stronami. Taka też forma cytowania będzie zastosowana w mojej pracy. Jak już wspomniałam, dzieło oksfordzkiego filozofa było rezultatem ponad trzydziestoletnich, burzliwych doświadczeń wojny i niepokojów. Autor zaczął je spisywać w przerwie, pomiędzy dwoma wojnami i jego celem było przypomnienie ludziom, o co walczą, a czego politycy nie chcieli wypowiedzieć na głos. Książka ta miała cel praktyczny: pomóc współczesnym w zażegnaniu obecnego konfliktu i uniknąć sytuacji, jaka miała miejsce podczas pierwszej wojny, gdy ludzie i sam autor nie wiedzieli, o co walczą, a przywódcy polityczni nie byli w stanie lub nie chcieli tego wyartykułować.

Zob. R. G. Collingwood, The idea of history, Oxford 1961. W dziele tym Collingwood prezentuje własną, autorską koncepcję rozumienia historii jako odtworzenia (re-enactment) w umyśle historyka minionych wydarzeń. Wiele uwagi poświęca tam sposobowi pojmowania historii przez starożytnych.

Tenże, The New Leviathan: Or Man, Society, Civilization and Barbarism, red. D. Boucher, Oxford 1992 oraz R. G. Collingwood, Essays in political philosophy, red. D. Boucher, Oxford 1995.

8 Tenże, The New Leviathan..., s. LX. W tym cytacie użyłam tłumaczenia J. Zdybel.

Tamże. 
Sama konstrukcja Nowego Lewiatana przypominała bardzo dzieło Hobbesa Lewiatan ${ }^{10}$. Nie tylko tytuł i wstęp do Nowego Lewiatana świadczyły o inspiracji Hobbesem. Sama budowa książki Collingwooda i jej treść stanowiły wyraźne odniesienie do twórczości angielskiego, „zapomnianego”, filozofa ${ }^{11}$. Collingwood, podobnie jak Hobbes, podzielił swoje dzieło na cztery części. Co prawda autor Nowego Lewiatana planował umieszczenie jeszcze piątej części, w której chciał przedstawić cywilizacji europejskiej, w jaki sposób najlepiej odpowiedzieć na poczynania barbarzyństwa, ale w rezultacie nigdy jej nie napisal ${ }^{12}$.

Jakie problemy podjął autor w tej rozprawie? Dzieło to było próbą ukazania na podstawie historycznych śladów, dowodów, pozostałości historycznego procesu rozwoju europejskiego umysłu jako kumulatywnego gromadzenia i łączenia elementów niespołecznych ze społecznymi. To także próba odnalezienia związków między teorią i praktyką. Collingwood był przekonany, że na początku pojawiło się jakieś wydarzenie, które było analizowane przez filozofię, by w efekcie zmodyfikowane przez refleksje powrócić do praktyki. Tym wydarzeniem, które natchnęło go do rozważań, jest przypadek Niemiec i ich nazizmu. Praca filozofa była utrzymana w tonie jawnie antyhitlerowskim. Pojawiły się nawet wypowiedzi pochlebne na temat Marksa i marksizmu, choć sam autor był też i jego krytykiem. Collingwood cenił w Marksie to, że ten angażował się w myśl polityczną. Autor Nowego Lewiatana przyznał, że do momentu rozpoczęcia nad nim pracy był daleki od angażowania się w sposób jawny w walkę polityczną, ale zmienił zdanie i chciał mieć wpływ na poglądy Brytyjczyków. Pochlebne wypowiedzi na temat Marksa przyczyniły się nawet do prób określania tego liberalnego filozofa jako marksisty. Tezę taką wysunął jego uczeń Thomas Malcolm Knox. Ostro sprzeciwiło się jej wielu innych badaczy, jak David Boucher czy John Patrick ${ }^{13}$.

Ale czym był tytułowy Lewiatan, co on oznaczał? Lewiatan pojawił się już u Platona, który opisywał go jako wielkogłowe zwierzę ogarnięte pożądaniami $^{14}$. Bardzo dużo odniesień do Lewiatana można było znaleźć w judaizmie, Biblii i chrześcijaństwie. Biblia niejednokrotnie przedstawiała rozmaite wizje tego stwora i za każdym razem miał on negatywny charakter.

\footnotetext{
Zob. T. Hobbes, Lewiatan czyli materia, forma i władza państwa kościelnego i świeckiego, przeł. Cz. Znamierowski, Warszawa 1954.

R. Tokarczyk, Hobbes, Warszawa 1987.

D. Boucher, Editor's introduction, [w:] R. G. Collingwood, The New Leviathan..., s. XIII.

Szerzej na ten temat pisze W. M. Nowak, Robina G. Collingwood'a filozofia historii, Lublin, 2002, s. 32 .

Zob. C. Schmitt, Lewiatan w teorii państwa Tomasza Hobbesa, przeł. M. Falkowski, Warszawa 2008, s. 14.
} 
Lewiatan mógł być starotestamentowym, ujętym mistycznie zwierzęciem, takim jak: morski potwór (przeciwieństwo potwora lądowego - Behemota), krokodylem, wielorybem, wielką ryba. Często też obraz tego monstrum zlewał się w jeden: w postać węża lub smoka. Co nie ulega wątpliwości, w biblijnych przedstawieniach jego postaci, miał ma on niewątpliwie zły charakter i był powiązany z szatanem ${ }^{15}$. Także tradycja żydowska (biblijna, talmudyczna i kabalistyczna) widziała w Lewiatanie uosobienie - jeśli nie zła wcielonego - to wroga: Babilonu, Asyrii czy Egiptu.

Wrogie określenia historyczne Lewiatana pojawiły się także w legendach i mitach traktujących o bohaterach, pogromcach smoków czy potworów, jak: Zygfryd lub św. Jerzy ${ }^{16}$. Średniowiecze przywykło do określania Lewiatanem zła i szatana. Według Schmitta tylko tradycja chińska widzi w nim pozytywne aspekty.

Pewien przełom w rozumieniu Lewiatana nastąpił dzięki Hobbesowi, chociaż przed nim na ten temat pisali i inni pisarze, filozofowie oraz teolodzy. Stopniowo poprzez wieki Lewiatan tracił swój negatywny wydźwięk. Być może przyczynia się do tego też Hieronim Bosch i Peter Breughel Młodszy (tzw. piekielny).

W czasach współczesnych Hobbes był filozofem kojarzonym ze względu na jedno swoje dzieło, bywał nawet nazywany "prorokiem Lewiatana"17. Ale według Schmitta tytuł Lewiatan, czyli materia, forma $i$ władza państwa kościelnego $i$ świeckiego bardziej zaszkodził jego autorowi niż pomógł. Nawet, jeśli weźmiemy pod uwagę fakt, że swoich badaniach Hobbes dążył do „nadania wiedzy o polityce tej ścisłości niepodważalności, które znane są w geometrii i fizyce" ${ }^{, 18}$, to i tak opinie o tym filozofie - ze względu na jego poglądy - były negatywne.

Według Carla Schmitta Hobbes wnikliwie i krytycznie czytał Biblię, ale nie odnosił się do niej zbyt często. Lewiatan dosłownie był po prostu „cytatem z Biblii [i] unaoczniał najsilniejszą władzę doczesną w postaci zwierzęcia, którego niezwykła siła powstrzymuje wszystkie słabsze"19. Nie oznacza to, że u Hobbesa Biblia i religia odgrywały jakąś pozytywną rolę, ponieważ w swoich traktatach poświęconych człowiekowi i państwu dążył do zerwania ze średniowiecznym sposobem myślenia o państwie powiązanym nieodłącznie $\mathrm{z}$ religią. Filozof $\mathrm{w}$ swoich postulatach nawoływał do uwolnienia polityki od teologii. Koncepcja ta była tak nowatorska i nietypowa w czasach, w któ-

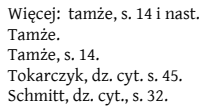


rych żył, że pojawiały się i opnie, że Lewiatan na tle innych koncepcji z filozofii polityki jest dziełem, które „rozsadzało ramy wszelkiej abstrakcyjnej jedynie teorii czy konstrukcji,"

Lewiatan był, najprościej rzecz ujmując, symbolem państwa. A państwo stanowiło sztuczny twór, wynik ludzkiego rozumu i kalkulacji. Było pewnym neutralnym dziełem, które działało jak mechanizm. Ujmowano je także jako maszynę ożywiona przez suwerena, miało za zadanie tworzyć i bronić pokoju, gwarantować dotrzymywania umowy społecznej i bezpieczeństwo. Powstało właśnie jako wynik porozumienia przez jednostki w stanie natury. Lewiatan zabezpieczał swoich obywateli, chronił, rozsądzał spory. W swoim charakterze był transcendentny i zawsze obecny, potencjonalnie aktywny zabezpieczał poddanych przed chaosem, a także terrorem Kościoła. Posiadał najwyższy autorytet, ale to nie znaczy, że rościł sobie pretensje do posiadania monopolu na prawdę. Utworzenie państwa kończyło wojnę panującą w stanie natury.

O wielkości państwa i jego zadaniu wiele mówiła okładka Lewiatana przedstawiająca ogromną postać składającą się z wielu małych ludzi. W prawej ręce ten ogromny człowiek dzierżył miecz, a w lewej pastorał. Rycina ukazywała jego rolę jako giganta sprawującego pieczę nad spokojnego miastem. Swoim zasięgiem obejmował zarówno elementy świeckie (zamek, koronę, broń), jak i duchowe (Kościół, kleryków, sobory i symbol władzy duchowej - czapkę papieską). Lewiatan u Hobbesa miał postać człowieka, ale filozof opisywał go również jako wielkie zwierzę, czasem odmalowywał go jako wielkiego, masywnego człowieka złożonego na wzór maszyny z mniejszych trybików - poszczególnych ludzi. Lewiatan jawił się również jako gigant, połączenie zarówno zwierzęcia, jak i człowieka, Boga i maszyny. Tak ujęty był według specjalistów symbolem państwa powstałego $\mathrm{w}$ wyniku umowy społecznej. Miał on szereg uprawnień do zarządzenia, ferowania wyroków, utrzymywania porządku, a nawet monopol na prowadzenie wojny.

Czym był Lewiatan u Collingwooda? Interpretacji było kilka. W przedmowie do pierwszego wydania Nowego Lewiatana oksfordzki filozof stwierdził, że czytelnik może potraktować jej tytuł, jakkolwiek by chciał.

Dla tych, którzy uważają podejście Hobbesa za przykład klasycznej myśli despotycznej, absolutystycznej, dzieło to mogło wydać się pewną wycieczką przedsięwziętą w celu opisania i zanalizowania nowego, dwudziestowiecznego absolutyzmu (nowego Lewiatana, czyli nazizmu). Absolutyzm ten opierał się na woli ludzi, którzy ustanawiali tyrana i oddają mu władzę 
dotychczas posiadaną ${ }^{21}$.W dziele tym autor zamierzał opisać wszelkie sukcesy (jak pokonanie wszystkich swoich przeciwników i bycie jedyną alternatywą formą polityczną w przyszłości) oraz porażki tego absolutyzmu. Filozof pragnął również wnieść swój wkład w obecne i przyszłe życie polityczne poprzez charakterystykę idei i instytucji, o których człowiek nigdy nie powinien był zapomnieć. Ta książka była próbą podzielenia się z czytelnikami własnymi refleksjami na temat człowieka, jego ciała, zdolności, aktywności, cnót, wad. Collingwood porusza w niej kwestie chrześcijańskiej „wspólnoty”, bądź też „federacji” (Christian Common-Wealth), czy „chorego porządku Królestwa Ciemności" (Kingdome of Darkness) ${ }^{22}$.

Drugie rozumienie tytułu i treści Nowego Lewiatana, które było bliższe samemu autorowi, pokazało, że dopiero XX wiek jest w stanie docenić wielkość myśli Hobbesa, jego mądrość polityczną. Niestety Hobbes nie zadowalał nikogo, nie miał grupy swoich czytelników. A żaden z polityków począwszy od XVIII w. nie był w stanie tak jak Hobbes zrozumieć siebie i innych ${ }^{23}$. W tym rozumieniu tytuł Nowy Lewiatan odsyłał bezpośrednio do idei Hobbesa.

Zasadniczym tematem omawianego przeze mnie dzieła Collingwooda była szeroko pojęta filozofia polityki, w skład której wchodziły omawiane kwestie, jak cywilizacja i społeczeństwo ${ }^{24}$. Aby zrozumieć jego filozofię polityczną konieczne jest zatem prześledzenie toku jego myślenia. Collingwood - tak jak Hobbes - swoje rozważania rozpoczął od opisania kondycji pojedynczego człowieka, jego cech charakterystycznych. Następnie wzorując się na swoim poprzedniku, pokazał proces przechodzenia ze stanu pierwotnego do społeczeństwa. W kolejnych rozdziałach swojej książki podjął kwestie społeczeństwa zdążającego ku cywilizacji i walki tejże ostatniej z wrogiem, jakim było barbarzyństwo.

Collingwood w Nowym Lewiatanie opisywał cywilizację poprzez ukazanie relacji pomiędzy ciałem jako obiektem fizycznym, biologicznym, a ciałem jako człowiekiem, członkiem wspólnoty politycznej oraz między społeczeństwem i państwem. W tym celu posługiwał się „kategoriami zmodyfikowanej teorii umowy społecznej” ${ }^{25}$. W książce oprócz odniesień do Hobbesa znalazły się również odwołania do takich teoretyków klasycznej polityki jak Locke czy Rousseau. W swej koncepcji umowy społecznej Collingwood korzystał również, jak sygnalizowałam, z doświadczeń Europy na przestrzeni wieków.

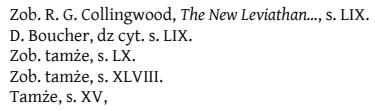


Według D. Bouchera ta wersja kontraktualistycznej filozofii była dużo bardziej elastyczna i zróżnicowana niż poprzednie. Collingwood pewne aspekty ujął w sposób bardziej szczegółowy i subtelny, chociaż mógłby omówić, przykładowo, problem obywateli, którzy mieli znikomy udział we współrządzeniu poprzez wybory, bo byli na to zbyt apatyczni lub niedojrzali ${ }^{26}$.

Autor Nowego Lewiatana krytykował swoich poprzedników zajmujących się kwestiami umowy społecznej za brak bądź też nieadekwatne scharakteryzowanie stanu natury ${ }^{27}$. Jego dzieło miało za zadanie naprawić to „przeoczenie" poprzez opis stanu natury obecny w życiu społecznym. Oksfordzki filozof rozpoznawał rozróżnienie pomiędzy stanem natury (state of nature lub non-social community) a wspólnotą, czy też społeczeństwem (social community). Należy też dodać, że częściej używał on terminu „wspólnota niespołeczna”, aby odróżnić ją od przyjętego przez tradycję terminu „stan natury".

Dla autora stan natury nie był pewnym wydarzeniem w historii, które już się skończyło. Stan natury wciąż był obecny w życiu politycznym i przejawiał się w osobach niedojrzałych do politycznych decyzji członków społeczeństwa, (były to dzieci, a także kryminaliści pozbawieni praw obywatelskich). Instytucje takie jak rodzina czy wspólnota polityczna miały za zadanie przygotować wszystkich uczestników społeczeństwa (najczęściej dzieci) do bycia pełnoprawnymi członkami wspólnoty, dojrzałymi do odpowiedzialności. Dla Collingwooda w pewnym momencie rozwoju człowiek niedojrzały, niespołeczny (w sensie nie będący w pełni członkiem społeczeństwa), na pewnym etapie rozwoju mentalnego, zwanego rozumem praktycznym, obdarzony wolną wolą (freedom of the will) był w stanie dojść do porozumienia z innym ludźmi. Filozof pojmował wolność jako stopniowy proces, jako stan świadomości. We fragmencie 34.25 stwierdzil, że wolność ma dwa aspekty: pozytywny i negatywny. Pozytywnie oznaczała wolność do jakiegoś wyboru, hartowania własnej woli. Negatywnie rozumiana wolność, to uwolnienie się od pożądań ${ }^{28}$. Dla liberała i demokraty, jakim był Collingwood, wolność była niezbędna do prawidłowego funkcjonowania w społeczeństwie, stanowiła wręcz nieodzowny elementem dojrzałej, rozumnej wspólnoty.

Dojrzałości mentalnej autor nie rozumiał jako jakiś absolutny, zobiektywizowany standard. Był to stan umysłu. Nie oznaczała ona przekroczenia cezury pewnego wieku. Była to umiejętność okiełznania własnych namiętno-

Zob. tamże, s. XLV.

Collingwood używał częściej sformułowania „stan przed-społeczny” pisanego z myślnikiem pomiędzy na podkreślenie faktu, iż w stanie pierwotnym, stanie natury nie ma społeczeństwa

28 Powraca tu ideał stoików i jak twierdzi Nowak grecka paidea, zob. Nowak, dz. cyt. s. 128. 
ści, polegająca na wolnej woli. Funkcjonowała jako pewien wzorzec zachowań powstały w wyniku wpływu otoczenia i okoliczności, w jakich żyły jednostki. Charakteryzowała się ona pewną nieugiętością ze względu na pre$\mathrm{sję}^{29}$. Była to umiejętność okiełznania własnych namiętności.

Collingwood rozumiał ciało i umysł jako jedność, na sposób monistyczny, podobnie jak Hobbes. Ten ostatni był przekonany, że całość otaczającego go świata jest „albo ciałem, albo własnością” rozumianą jako dyspozycją ciała, która odróżnia je na tle innych. To, że tego nie dostrzegamy, to wynik słabości naszego ciała ${ }^{30}$. Podobnie wyglądał ten problem u Collingwooda, który w swoich dziełach prezentował takie stanowisko. Człowiek w tym wypadku nie dzielił się na duszę i ciało, stanowił pewną harmonijną całość, o częściach której mogli wypowiedzieć się różni specjaliści. Ciało ujmowali oni na różne sposoby. Dla przyrodnika było ono bardziej istotne niż umysł, a dla naukowców, biologów to umysł był ważniejszy. W swoich poglądach Collingwood był monistą, który nie wykluczał różnych sposobów ujmowania i pojmowania człowieka.

Z rozważań nad kondycją poszczególnych ludzi, pojedynczych atomów przeszedł, podobnie jak Hobbes, do rozważań na temat koncepcji jednostki jako członka społecznego. Społeczeństwo było wspólnotą, złożoną z poszczególnych ciał (ludzi), którą łączyła świadomość społeczna jednostek jako członków większej całości (w tym jest on podobny do Hobbesa). Wspólnota składała się z mentalnie dojrzałych dorosłych, obdarzonych bardzo ważną dla funkcjonowania społeczeństwa, wspomnianą już wolną wolą ${ }^{31}$. Według Collingwooda społeczeństwo było podobne do społeczeństwa rzymskiego i rozumiał je jako stowarzyszenie wolnych jednostek, których wolność jest ograniczona wzajemnie poprzez umowę ${ }^{32}$. Kto był sygnatariuszem umowy społecznej? Osoby dorosłe fizycznie i mentalnie, odznaczające się świadomością wolnej woli ${ }^{33}$.

Występowanie wolnej woli było niezbędnym elementem wspólnoty. Jednak wola pewnych członków wspólnoty w ogóle mogła być odebrana jako pogwałcenie woli innych. W charakterystyce tej sytuacji powrócił filozoficzny problem wolności i jej ograniczeń. Zdaniem Collingwooda występował tutaj pewien element przemocy, ograniczenie wolności, ale dotyczył on tylko wspólnoty niespołecznej (przykładowo dzieci) i siła ta miała nie charakter

Zob. R. G. Collingwood, The New Leviathan..., 20.62, 21.8-21, 23.46.

R. Tokarczyk, dz. cyt., s. 58.

Zob. D. Boucher, dz. cyt. s. XLIII.

Społeczeństwo to „a «social contract» is a «consensual» like purchase-and-sale; its essence is simple agreement of will", zob. R. G. Collingwood, The New Leviathan..., 19.53.

Zob. tamże, fragment 20.30 . 
dosłowny, a raczej symboliczny, mentalny ${ }^{34}$. Do sprawnego rządzenia ciało polityczne (rząd, wspólnota uspołeczniona) musiało po prostu okiełznać tkwiące wewnątrz niego żywioły, które pozostają na zewnątrz społeczeństwa i nie będą w stanie rządzić same sobą.

Umowa społeczna, „sygnowana” przez dojrzałych mentalnie ludzi umoźliwiała przejście ze stanu natury w społeczeństwo. Sam proces „cywilizowania” nigdy nie był zakończony, a społeczeństwo wciąż i na nowo „rekrutowało" nowych członków spośród swoich wychowanków, czyli dzieci ${ }^{35}$. $Z$ tego też powodu cywilizacja była raczej dążeniem, a nie elementem statycznym, o czym napiszę później.

Dla filozofa proces socjalizacji i proces cywilizowania były jednym i tym samym, ponieważ jako konieczny element w budowaniu wspólnoty zakładały wykluczenie przemocy z relacji międzyludzkich. Przemoc nigdy nie była do końca wyeliminowana, bo jak już wspomniałam, na społeczeństwo składali się również członkowie „niedojrzali” bądź pozbawieni praw i wobec nich elementy przemocy wciąż były stosowane. Collingwood miał nawet pewną ideę, aby podzielić społeczeństwo ze względu na poziom dojrzałości jego członków i siłę wolnej charakteru. Pisał o tym szerzej w rozdziale $25^{36}$.

Podział na jednostki dojrzałe i niedojrzałe w społeczeństwie znalazł odzwierciedlenie w koncepcji władzy państwowej mającej dwojaki charakter. Była ona immanentna, bo do rządzenia dopuszczano tych, którzy mogli rządzić sobą, czyli posiadali pełnię praw w społeczeństwie. Władza była też transcendentna w tym sensie, że rządziła innymi, a nie sobą, to znaczy miała poddanych. Takie współzależności były widoczne nie tylko w państwie, ale też w rodzinie. $O$ co tutaj chodzi? Pierwsza część (obywatele, rodzice) składała się z członków dojrzałych, którzy wyłaniają spośród siebie rząd. Druga warstwa natomiast rekrutowała się z członków wspólnoty przedspołecznej, niespołecznej (dzieci). Wspólnotę niedojrzałych nazywał autor szkółką, żłobkiem (nursery). Z takim podziałem społeczeństwa na dwie warstwy wiązały się dwie reguły rządzenia: demokracja i arystokracja. Collingwood zauważył, że te pojęcia są często źle rozumiane. Zarówna arystokracja, jak i demokracja w swym działaniu przybierały postać trzech uniwersalnych praw politycznych.

Pierwsze prawo głosi, że „państwo podzielone jest na dwie klasy: rządzących i rządzonych" ${ }^{\text {,7 }}$. Drugie prawo mówiło, że granica pomiędzy tymi „klasami jest przenikliwa w kierunku wstępującym” - rządzeni mają prawo

\footnotetext{
Zob. J. Zdybel, dz. cyt. s. 132.

Tamże, s. 133.

R. G. Collingwood, The New Leviathan..., 25.41-49.

Tamże, s. 25.7.
} 
do awansu politycznego ${ }^{38}$. Trzecie prawo nakładało na rządzących obowiązek bycia wzorem do naśladowania dla społeczeństwa ${ }^{39}$.

Jaka była różnica między arystokracją a demokracją, skoro działały one według tych samych praw? Różnica demokracja-arystokracja zasadzała się na stosunku rządzących do rządzonych. Według oksfordzkiego filozofa demokracja dążyła do powiększenia klasy rządzącej o wszystkich chętnych, którzy przyczyniliby się do zwiększenia jej siły. Natomiast arystokracja z obawy przed osłabieniem rządzących stara się ograniczać liczbę biorących udział w rządzeniu. Klasa rządzących musiała dopuszczać do siebie innych, pełnoprawnych członków wspólnoty, co oznacza postępowanie zgodnie z wolą społeczeństwa. Demokracja była otwarta na innych, a arystokracja zasadzała się na zasadzie ekskluzywności swoich członków. Niezależnie od tego, czy rząd był demokratyczny, czy arystokratyczny zapewniał on spokój i bezpieczeństwo. W jaki sposób to czynił? Collingwood był przekonany, że taka sytuacja miała miejsce dzięki autorytetowi. To, „co odkrył Hobbes to to, że „państwo" (state) lub suweren (sovereign) wcale nie rządzi siłą, ale nadal rządzi, rządzi za pomocą autorytetu. On (suweren) rządzi, ponieważ jego poddani (constitent subjects), którzy są - niektórzy z nich, nie wszyscy - po obu stronach granicy oddzielającej człowieka jako istotę społeczną od człowieka w stanie natury; osiągnęli (poddani) życie społeczne i dlatego też są w stanie nadać (mu) władzę ${ }^{40}$. Collingwood uznaje stwierdzenie tego faktu za wielkie odkrycie Hobbesa dokonane w naukach politycznych. Było to na tyle ważne, że poprzednie wydarzenie tej rangi miało miejsce w czasach Arystotelesa.

Rząd i suweren swoim panowaniem obejmowali wszystkich, całość społeczeństwa zarówno obywateli dorosłych, jak i tych, którzy aspirowali do bycia dorosłymi (dzieci, żłobek). Tak ujęta wspólnota była tożsama z cywilizacją. „W Nowym Lewiatanie cywilizacja jest opisana jako proces zdążający ku ideałowi społeczeństwa, którym jest nieobecność siły w relacjach między jednym a drugim, do którego (ideału) możemy się ciągle zbliżać z powodu nieustającej obecności niespołecznych elementów w różnorodnym (mixed) społeczeństwem, nazywanym przez nas ciałem politycznym (rząd - body politic)" ${ }^{\text {"41 }}$. Esencją cywilizacji dla Collingwooda było społeczeństwo, które dążyło do porozumienia i to dążenie zapewniało mu ciągłość i trwałość procesu cywilizacyjnego.

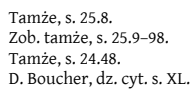


Jak można rozumieć cywilizację? W Nowym Lewiatanie i w innych pismach Collingwood nie podał żadnej rozbudowanej koncepcji cywilizacji. Najbardziej interesowała go cywilizacja nie jako finalny produkt, a raczej jako proces dochodzenia do niej. Problemy cywilizacji omówił on szeroko w trzeciej części swojej książki i można mniemać, że ta część pracy powstała najpóźniej, gdyż zarys pracy utworzony został na ponad 20 lat przed jej wydaniem w $1942 \mathrm{r}$. We fragmencie 34.25 i następnych filozof analizował potoczne rozumienie terminu „cywilizacja”. Podał on trzy definicje: cywilizacja jako: proces cywilizowania społeczeństwa, efekt tychże zabiegów, pewną ideę regulatywną, do której dąży społeczność. Dla filozofa cywilizacja była właśnie pewnym dążeniem ku celowi, a nie jego osiągnięciem. Czym zatem była cywilizacja? To pewne pokonywanie coraz to nowych szczebli rozwoju. Niecywilizowana, niespołeczna część wspólnoty staje się społeczna. Odbywało się to w trakcie edukowania coraz to nowych członków rozrastającej się wciąż wspólnoty niespołecznej (dzieci). To ciągłe odnawianie umowy społecznej, poszerzanie wspólnoty o młodych członków.

We fragmencie 34.51 Collingwood stwierdził, że cywilizowanie to „przybliżanie się do idealnego państwa”. Wspólnota była miejscem, w którym cywilizacja się niejako odgrywała, to społeczność dążąca do ideału. Ludzie, członkowie takiego cywilizującego się społeczeństwa, musieli wyzbyć się egocentryzmu i w swoim postępowaniu kierować się wspólnotą, a nie partykularnym interesem.

O jakości cywilizacji świadczą nie tylko relacje wewnątrz wspólnoty, ale również relacje z innymi ludźmi (na zewnątrz wspólnoty) oraz stosunek do otaczającego świata. We fragmencie 35.41 Collingwood prezentował właściwe podejście człowieka cywilizowanego do innych. Człowiek cywilizowany miał przede wszystkim powstrzymać się od wywoływania w drugim jakiejkolwiek namiętności (niepokoju, strachu), aby dana osoba nie straciła opanowania. Dodaje też, że niepożądane było, by w wyniku kontaktu jednego cywilizowanego człowieka z drugim (niekoniecznie ucywilizowanym), ten drugi stracił szacunek do siebie. Ludzie cywilizowani dążyli do pokojowych i zgodnych relacji ze wszystkimi, nie tylko z członkami własnej wspólnoty.

Ucywilizowanie dotyczyło nie tylko relacji międzyludzkich, ale też stosunku do natury. Inteligentna eksploatacja natury zależała od „ducha zgody" przenikającego społeczeństwo. To ono, korzystając ze wspólnego dziedzictwa nauk praktycznych, miało tak pieczołowicie zarządzać środowiskiem, aby zaspokoić swoje potrzeby (żywieniowe itd.) ${ }^{42}$. Dobre zarządzanie wspólnotą, jak i środowiskiem miało prowadzić do wydobycia esencji cywili-

R. G. Collingwood, The New Leviathan, 39.1-94. 
zacji, jakimi były: edukacja (młodych pokoleń), dobrobyt, prawo i porządek, pokój i obfitość (plenty) ${ }^{43}$.

W tak dobrze zorganizowanym społeczeństwie nie było większych nierówności, panowała sprawiedliwość rozumiana jako równa dystrybucja dóbr pomiędzy pełnoprawnymi członkami społeczeństwa. Dobrobyt był rezultatem życia w cywilizowanym, dobrze zorganizowanym społeczeństwie. Obok zdrowia i pokoju charakteryzował wysoko zorganizowaną i harmonijną wspólnotę. Dobrobyt oznaczał zwrot ku pewnym standardom, które oczywiście mogły ulegać zmianom. Bogactwo narzucało swego rodzaju nierówny stosunek, przewagę między biednym a bogatym. „Użycie tego typu siły jest afrontem dla ideału cywilizacji” - która przecież wyrzekła się przemocy ${ }^{44}$. Ideałem byłby brak tejże nierówności. Niewielkie dysproporcje pomiędzy bogatymi a biednymi mogły być dopuszczone jedynie, gdy były adekwatną rekompensatą dla najbardziej poszkodowanych. Koszt tego wyrównania miała ponieść cała wspólnoty. „Obecność kontrastu pomiędzy bogactwem a biedą, nawet niewielkiego kontrastu, stanowi element barbarzyństwa w cywilizacji", bo ucywilizowana wspólnota nie toleruje wielkich nierówności wewnątrz siebie ${ }^{45}$.

Taki idylliczny obraz nie był oczywiście rzeczywistością, a raczej celem, który powinien przyświecać wszystkim światłym członkom społeczeństwa. Collingwood zdawał sobie sprawę z tego, że nie dało się nigdy wyeliminować siły $\mathrm{z}$ relacji międzyludzkich, chociażby mając na uwadze przestępców. Poza tym pewien element siły, czy może paternalizmu zawsze był obecny we wspólnocie, a jego ofiarą były osoby niedojrzałe emocjonalnie, niespołeczni członkowie społeczeństwa.

Cywilizacja nie zawsze rozwijała się harmonijnie. Nastąpiły w dziejach pewne elementy załamania, kryzysu, które na szczęście za każdym razem były przezwyciężane. Tymi kryzysami było narodzenie się barbarzyństwa, które stanowiło przeciwieństwo cywilizacji. Barbarzyństwo to świadome rezygnowanie z ideałów cywilizacji i odwrót w stronę pasji, namiętności i pożądań. Nie każda wspólnota niecywilizowana oznaczała automatycznie popadanie w stan barbarzyństwa. Collingwood pisał także o dzikości (savagery) jako o byciu po prostu niecywilizowanym, a nie świadomym odwrocie od cywilizacji.

Barbarzyństwo zaprzeczało istnieniu cywilizacji, która aby przetrwać musiała wciąż z nim walczyć. Pisząc językiem Hobbesa, można powiedzieć,

\footnotetext{
Tamże, 39.17-21.

D. Boucher, dz. cyt. s. XLVII.

R. G. Collingwood, The New Leviathan..., 38.77.
} 
że jest to próba zerwania umowy społecznej i powrót do stanu pierwotnego, gdzie człowiek zamiast logiki kierował się emocjami. Barbarzyństwo pojawiło się w dziejach cztery razy. Autor Nowego Lewiatana twierdził, że barbarzyńcy w walce z cywilizacją zawsze przegrywali i zawsze będą przegrywać. Na dowód podał trzy zwycięskie starcia z barbarzyństwem. Pierwszy jego przejaw - scharakteryzowany obszernie w rozdziale 42 - miał miejsce w VII wieku, gdy Europę zaatakowali saraceni. Drugiemu barbarzyństwu, herezji Albigensów w XIII w., poświęcił rozdział 43. Żyjących pod koniec średniowiecza Turków, jako trzecich, zaprezentował w rozdziale 44.

Ostatnim rodzajem barbarzyństwa, z jakim mieliśmy do czynienia na przestrzeni wieków, stanowiło barbarzyństwo Niemców, którzy według Collingwooda wcale nie byli tak unikatowi i niepowtarzalni, jak im się wydawało. Filozof uważał, że Niemcy to barbarzyńcy i że rodzili się bez manier ${ }^{46}$. Mimo pewnych podejrzeń co do odwiecznego barbarzyństwa Niemiec, Collingwood stwierdził, że proces narodzin barbarzyństwa przebiegał stopniowo i część zjawisk działa się niejako w ukryciu, wewnątrz Niemiec ${ }^{47}$, chociaż za początek narodzin można „nieściśle” uznać „epokę Bismarcka”. zizm i barbarzyństwo według filozofa odpowiadały za II wojnę światową, ale krytyka Niemców nie dotyczyła całego narodu niemieckiego ${ }^{49}$. Nie wszyscy Niemcy byli źli, pojawiali się nawet herosi walczący z nazizmem, ale nie stanowili całości narodu niemieckiego.

W ogólnym ujęciu „Collingwood wierzył, że liberalizm i odtąd cywilizacja europejska jest atakowana ze wszystkich stron; nie tylko przez polityczną Lewicę i Prawicę, lecz także przez więcej generalnych, intelektualnych trendów podczas tego (XX w. - przyp. B. S.) wieku, ale wywodzących się z wcześniejszych czasów" ${ }^{, 50}$. Tymi tendencjami były głównie nazizm, faszyzm włoski i autorytarne podejście czyniące $\mathrm{z}$ władzy współczesnego Lewiatana.

Na temat odpowiedzialności Niemiec za II wojnę powstał szereg rozmaitych prac, studiów i badań. Część badaczy oskarżała o zbrodnie przywódców politycznych i oddzielała ich od narodu. Inni uważali nazizm za infekcję, a jeszcze inni ujmowali go jako podporządkowanie się ludu jednostce charyzmatycznej, prymitywnemu liderowi. Wreszcie pojawiły się głosy, które swo-

\footnotetext{
„They seem to have been born without any manners, as Mongols are born without any beards", tamże, 45.12 .

Zob. tamże, 45.25 .

Tamże, 45.4 .

Zob. tamże, 45.68 .

D. Boucher, Editor's Comments, [w:] R. G. Collingwood, Essays in political philosophy, Oxford 1989 , s. 163.
} 
je opinie opierały na psychologii, twierdząc, że wybuch wojny był spowodowany przez kompleks niższości, agresję i romantyzm, a ucieleśnieniem i reprezentantem tychże cech był Adolf Hitler. Naród niemiecki, również obdarzony tym konglomeratem cech podążył za liderem ${ }^{51}$. Przyczyny te spowodowały wybuch II wojny światowej i zalanie Europy przez Niemców i ich sprzymierzeńców. W jednym z rozdziałów swojego eseju Cywilizacja utylitarna Collingwood wymienia nawet cały szereg narodów, raczej ras (race) zaatakowanych przez niemiecki imperializm (absolutyzm) ${ }^{52}$.

Sam autor Nowego Lewiatana zapatrywał się na problem odpowiedzialności Niemiec za wojnę w zgoła inny sposób. Uważał, że wina leżała po stronie narodu. Hitler nie był szalonym dewiantem, który „uwiódł” bezbronny, niczego niepodejrzewający lud. Przyrównywał przywódcę Trzeciej Rzeszy do platońskiego tyrana, który działał na fali, niesiony był przez lud, nad którym nie miał kontroli ${ }^{53}$. Niemców nazywał bydłem lub stadem i dodawał do tego przymiotnik „świątobliwy”, podkreślając swój negatywny do nich stosunek (herd worship). Był przekonany, że stado Niemców stworzyło sobie liderów, którzy zachowywali się jak tłum, byli opętani emocjami i odruchami.

Nazizm niemiecki, odkąd powstał, rządził się odrębnym stylem myślenia. Collingwood twierdził nawet ,nie jestem pewien czy nazizm rozumie, do czego służy logika" ${ }^{54}$. Autor Nowego Lewiatana zadawał sobie pytanie, dlaczego naziści myśleli „swoją krwią” (postępowali emocjonalnie), a nie mózgami jak dotychczas? Pisząc to, miał na myśli ich impulsywność i odwoływanie się do emocji. Taki sposób myślenia nie był ani niczym nowym, ani niczym wyzwalającym, tylko czynił z Niemców niewolników. Byli skazani na porażkę, bo bali się wyzwania, jakim jest wolność i związana z tym odpowiedzialność, woleli zaciszne bezpieczeństwo pod przywództwem lidera. Niemieckie doświadczenia $\mathrm{z}$ wolną wolą stanowiły rzadkie zjawisko. Niemcy byli represjonowani i pozbawiani wolności począwszy od XV w. na życzenie władców, uważających poddanych za niezdolnych do racjonalnego myślenia lub co najwyżej widzących w nich tych, którzy wypaczali owo myślenie racjonalne. Filozofia pruska (duch pruski, jak pisał Spengler) dla Collingwooda stanowiła swego rodzaju chorobę, skażenie. Przejawem tego wypaczenia była już filozofia Artura Schopenhauera, Edwarda Hartmanna, Friedricha Nietzschego.

Filozofowie niemieccy na podstawie twierdzenia, że człowiek był w pewnym sensie anima socjalis, produktem społeczeństwa i spełniał się w kooperacji z innymi, wysnuli wniosek, iż cała kreatywność i inicjatywa

Zob. D. Boucher, Editor's introduction..., s. L.

Zob. R. G. Collingwood, Essays..., s. 201 i nast.

R. G. Collingwood, The New Leviathan..., 25.9-98.

Tamże, 45.3. 
wywodziła się ze strony państwa. Cechą charakterystyczną tego państwa była lewiatanowska moc, brak jakichkolwiek obowiązków wobec innych. Pierwszym przedstawicielem takiego myślenia był Hegel, który dał niejako impuls do rozwoju dwóch innych nurtów na podstawie swojej twórczości: monarchizmu i socjalizmu. Monarchizm jako pewien trend wyrażał przekonanie, że najważniejszą była osoba władcy. Socjalizm podkreślał pewny bezwarunkowy stosunek dyktatorski do proletariatu. Takie błędne rozumienie państwa jako absolutnego tworu było pomyłką filozofii niemieckiej. Nie było jednego uniwersalnego, totalnego, Hobbesowskiego wzorca państwa, tylko ich wielość. Złe rozumienie świata, błędna filozofia, którą Collingwood rozumiał jako „duchową chorobę" spowodowało I wojnę światową i ta też błędna filozofia wywoła nawrót tychże działań podczas II wojny. Niemcy nie rozumieli, że społeczeństwo to free joint activity ${ }^{55}$. Błędem było również zrównanie państwa z klasą rządzącą i zrównanie z całym ciałem politycznym (które było pojęte jako wspólnota niespołeczna) i rozumiane jako socjalizm.

Niemcy w swym upojeniu się barbarzyństwem uwielbiali sami siebie, przepadali za manifestowaniem swojej siły i potęgi. To czcigodne stado (herd worship, bydło) nie było w stanie samo się wyzwolić spod wpływu lidera ${ }^{56}$. Woleli oni ślepe posłuszeństwo nazizmowi, który był przekonany, że uratuje świat przed „zepsutą" Europą i próbowali zwalczyć całą Europę. W związku z wcześniejszymi doświadczeniami Collingwood był przekonany, że obecne zagrożenie dla cywilizacji europejskiej, jakim byli Niemcy ze swoim faszystowskim barbarzyństwem, też będzie zażegnane. Dzieło niemieckie nie mogło odnieść sukcesu, bo jak mogło zniszczyć coś, co nie istnieje? We fragmencie 41.68 Collingwood po raz kolejny powtórzył, że „nie ma czegoś takiego jak cywilizacja" (there is no such thing as civilization), a tylko wiele dróg do niej prowadzaacych. „Gdyby były, mogłyby być zniszczone i barbarzyństwo wygrałoby" "57. Barbarzyńcy zawsze mogli zniszczyć dzieła cywilizacji, ale pamięć o niej nie zaginęła. Zawsze byli tacy, którzy przechowali wiedzę o ideałach, by ją podtrzymać w okresie zagrożenia.

W filozofii politycznej Collingwooda widoczne są bezsprzecznie elementy filozofii Hobbesa. Rysy wspólne dotyczyły zwłaszcza koncepcji umowy społecznej. Tak jak u Hobbesa, tak u Collingwooda państwo i społeczeństwo były wynikiem porozumienia się poszczególnych jednostek. To, co łączyło obu filozofów, to także podejście monistyczne w rozumieniu człowieka i świata, choć monizm Collingwooda był dużo bardziej stonowany. Nie

Tamże, 33.46.

Zob. tamże, 87-88.

Tamże, 41.68 . 
można też pominąć wspólnej dla obu koncepcji stanu natury, która była czymś niewygodnym dla poszczególnych osób i niosła pewien dyskomfort. Collingwood, podobnie jak Hobbes, pisał swoje dzieło w konkretnym celu: obronie państwa, gdy to znajduje się w zagrożeniu.

Nie bez znaczenia pozostawał również fakt częstego odnoszenia się do Hobbesa, a nawet bezpośredniego cytowania Lewiatana. W Nowym Lewiatanie znajduje się około 30 odniesień do Hobbesa lub cytatów z Lewiatana, co także świadczy o dużym szacunku i inspiracji nowożytnym filozofem.

B O G U M I A S Z C Z E P A N I K - K R U S I N S K A 


\section{Abstract}

The article presents political philosophy of Robin George Collingwood, which was influenced by Thomas Hobbes, especially his masterpiece of 'LEVIATHAN or the matter, form and power of a COMMONWEALTH ecclesiastical and civil'. Collingwood, who was generally famous for being an archaeologist and historian, showed himself in one of his last books ('The NEW LEVIATHAN or Man, Society, Civilization and Barbarism'), as an engaged philosopher of politics. The fact that Collingwood used the title 'New Leviathan' indicated his strong inspiration by the silhouette of Leviathan. In the history, the symbol of Leviathan was understood in many different ways: as sea monster, enormous fish, dragon, snake and many others. In the course of time the notion 'Leviathan' lost its negative meaning and became a symbol of a state, owing to philosophy of Hobbes. Described by him, Leviathan was a giant man, a machine, a mechanism defending the parts he consisted of - the people. The power of Leviathan was absolute. This absolutism appeared also in 'The New Leviathan', whereas in a different form - as Nazism. Collingwood described the Germans as Barbarians who not only invaded Europe but also poisoned it with their Hitler's ideology. 